\title{
A 1:1 ENERGETIC CO-CRYSTAL FORMED BETWEEN TRINITROTOLUENE AND 2,3-DIAMINOTOLUENE
}

\author{
Nilgün Sen ${ }^{1,2}$ \\ ${ }^{1}$ School of Chemistry, University of Edinburgh, Edinburgh, EH9 3FJ, UK \\ ${ }^{2}$ Turkish National Police Academy, Institute of Forensic Sciences, Ankara, Turkey \\ nilgunsen2001@gmail.com; Nilgun.Sen@ed.ac.uk
}

\begin{abstract}
A 1:1 co-crystal of trinitrotoluene (TNT) and 2,3-diaminotoluene was prepared by solvent evaporation, and the structure of the co-crystal was determined by single-crystal and powder X-ray diffraction. The results indicate that the main mechanism of co-crystallization originates from the intermolecular hydrogen bonding (amino-nitro) and $\pi-\pi$ stacking. We also examined the Hirshfeld surfaces and associated fingerprint plots of the co-crystal and reveal that the structures are stabilized by $\mathrm{H} \ldots \mathrm{H}, \mathrm{O}-\mathrm{H}, \mathrm{O} \ldots \mathrm{O}$ and C...C $(\pi-\pi)$ intermolecular interactions. We analyzed the crystal packing and show its influence upon impact sensitivity. The results highlight that co-crystallization is an effective way to modify the sensitivity, oxygen balance and density of explosives.
\end{abstract}

Keywords: TNT; sensitivity; co-crystallization; safety; energetic materials

\section{1:1 ЕНЕРГЕТСКИ КО-КРИСТАЛ ОБРАЗУВАН ОД ТРИНИТРОТОЛУЕН И 2,3-ДИАМИНОТОЛУЕН}

Приготвен е 1:1 ко-кристал на тринитротолуен (TNT) и 2,3-диаминотолуен со испарување на растворувачот, а потоа е определена структурата на ко-кристалот со рендгенска дифракција на монокристал и на прашок. Резултатите укажуваат дека главниот механизам на ко-кристализација потекнува од интермолекулското водородно сврзување (амино-нитро) и од $\pi-\pi$ пластење. Исто така ги испитавме и површините на Hirshfeld и соодветните графички прикази на ко-кристалот и откривме дека структурите се стабилизираат со интермолекулски интеракции на Н...Н, О-Н, О...О и С...С $(\pi-\pi)$. Ја анализиравме структурата на кристалот и го покажавме нејзиното влијанието врз осетливоста на удар. Резултатите истакнуваат дека ко-кристализацијата е ефикасен начин да се модифицираат осетливоста, кислородната рамнотежа и густина на експозивите.

Клучни зборови: TNT; осетливост; ко-кристализација; безбедност; енергетски материјали

\section{INTRODUCTION}

Energetic materials, particularly explosives, have been commonly utilized in mining, armaments, space exploration and fireworks for many years [1]. During the last decade, one of the aims of the development of explosives has been to achieve high energy output, high safety and low cost. Energy output and safety are the most significant properties of explosives, with sensitivity to external stimuli being particularly important. In- deed, higher energy generally correlates with lower safety [2]. TNT is one of the most frequently used explosives for military and industrial applications owing to its low cost, ease of manufacture and ability to be safely melt-cast into munitions. However, TNT has a lower energy, negative oxygen balance and high sensitivity. As a result, further enhancements are still required in order to tune its properties. Researchers are interested in enhancing the performance of current explosives by modification of the crucial properties including sensitivity, 
density, melting point, packing coefficient and decomposition temperature [3-5]. Co-crystallization is a highly important technique that can be used to improve the physical and chemical properties of energetics without changing their chemical structures. This technique has been widely used in the field of pharmaceutical and material science [6-8]. The first reported co-crystal of TNT was a 1:1 TNT/pyrene co-crystal [9]. Subsequent TNT cocrystals have been reported, with one such report outlining 17 co-crystals of TNT, highlighting the physicochemical features that are modified through co-crystallization, including density, packing coefficient, melting point and decomposition temperature [10]. An energetic co-crystal comprising two energetic molecules has also been reported, namely TNT/CL-20. This co-crystal demonstrates high explosive power and reduced sensitivity compared to pure CL-20 [11-12].

In this paper, a non-energetic compound, 2,3-diaminotoluene, was selected as a candidate to form a co-crystal with TNT. The crystal structure of the co-crystal, Hirshfeld surfaces, decomposition temperature, crystal packing, oxygen balance and potential sensitivity are discussed. This new TNT co-crystal will provide new insights into future design of insensitive TNT co-crystals.

\section{MATERIALS AND METHODS}

\subsection{Materials and sample preparation}

TNT was synthesized from 2,4dinitrotoluene (DNT) according to a known procedure [13]. 2,3-Diaminotoluene was purchased from Sigma-Aldrich. Crystallization was performed by dissolving a 1:1 molar ratio of TNT $(1.57 \mathrm{mg})$, and 2,3-diaminotoluene $(0.84 \mathrm{mg})$ in $85 \%$ anhydrous methanol (approximately $3-5 \mathrm{ml}$ ) at $45^{\circ} \mathrm{C}$ and stirring for $30 \mathrm{~min}$, and chemical structures are shown in Figure 1.<smiles>Cc1c([N+](=O)[O-])cc([N+](=O)[O-])cc1[N+](=O)[O-]</smiles>

TNT<smiles>Cc1cccc(N)c1N</smiles>

2,3-diaminotoluene
Fig. 1. Chemical structures of TNT and 2,3-diaminotoluene
The solvent was allowed to evaporate at room temperature over a period of several days. Red crystals of TNT-2,3-diaminotoluene (TNTDAT) were formed and are depicted in Figure 2.

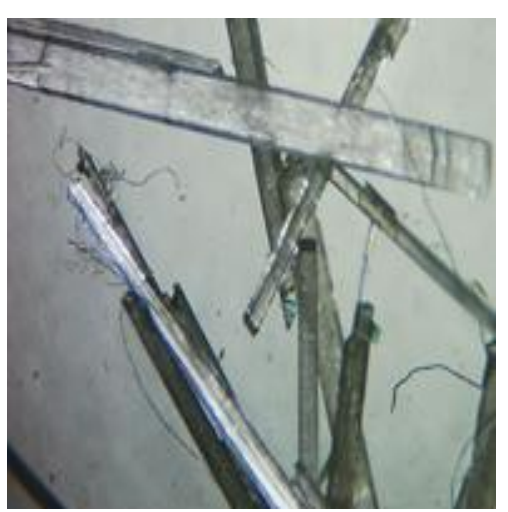

(a)

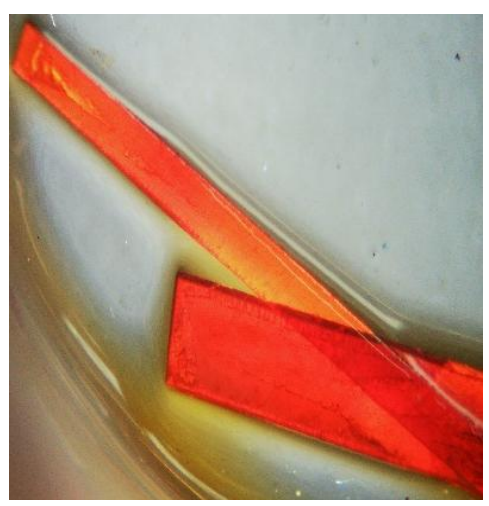

(b)

Fig. 2. Microscope images of (a) TNT, (b) TNT-DAT

\subsection{Single-crystal $X$-ray diffraction}

Single-crystal X-ray data for the TNT-DAT co-crystal were collected at $173 \mathrm{~K}$, using an Agilent Technologies Super Nova diffractometer equipped with an Oxford Cryo system. The structure was solved using Olex2 [14] and ShelXT software [15] and refined with the Shel XL [16] refinement package using Least Squares minimization.

\subsection{Powder X-ray diffraction (PXRD)}

PXRD patterns were recorded using the D2 PHASER Advance instrument using $\mathrm{Cu}-\mathrm{K} \alpha$ radiation $(\lambda=1.54439 \AA)$ and an operating voltage and current $40 \mathrm{kV}$ and $40 \mathrm{~mA}$, respectively. The data were collected over an angle range of $2 \theta=5-50^{\circ}$. This technique provided an initial screening of samples for formation of co-crystals. 


\subsection{Optical microscopy}

Optical micrographs of all the crystals were taken under the SK2005A polarization microscope. The macro-morphology of the crystals is a reflection of their microscopic structure, and the crystal morphologies are indicated in Figure 2. It can be observed that the co-crystals are red, with welldefined morphology, regular structure, uniform size and smooth surface. This differs from the shape of TNT, which exists as white plate crystals. The dissimilarity in morphology shows that cocrystal molecules have a different crystal structure and we may initially define the formation of the co-crystal.

\subsection{Differential scanning calorimetry}

DSC was performed on a NETZSCH STA 449 F1 Differential Scanning Calorimeter. $1.43 \mathrm{mg}$ of sample was placed in an aluminum pan and the thermal behavior of the samples was studied under a nitrogen purge $(30.0 \mathrm{ml} / \mathrm{min})$ at a heating rate of $10^{\circ} \mathrm{C} / \mathrm{min}$ over a range of $25-400^{\circ} \mathrm{C}$.

\subsection{Infrared spectroscopy}

The Infrared spectra were obtained by Fourier transform techniques with a Perkin-Elmer Spectrum 65 FT-IR spectrometer with ATR. Each spectrum was scanned in the range $400-4000 \mathrm{~cm}^{-1}$. Resolution ratio was $4 \mathrm{~cm}^{-1}$.

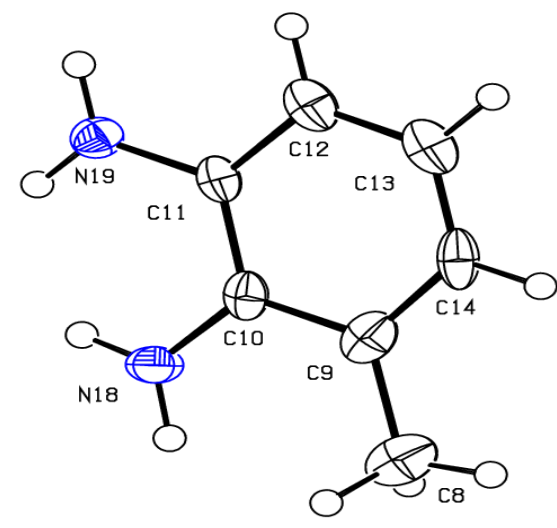

\section{RESULTS AND DISCUSSION}

\subsection{Structural characterization of TNT-DAT}

The PXRD patterns of the co-crystal, TNT and the co-former are shown in Figure 3. It is evident that the diffraction pattern of the co-crystal is clearly different from that of TNT and the coformer, indicating the formation of a new cocrystal.



Fig. 3. Comparison of PXRD patterns for 2,3-diaminotoluene, TNT and TNT-DAT

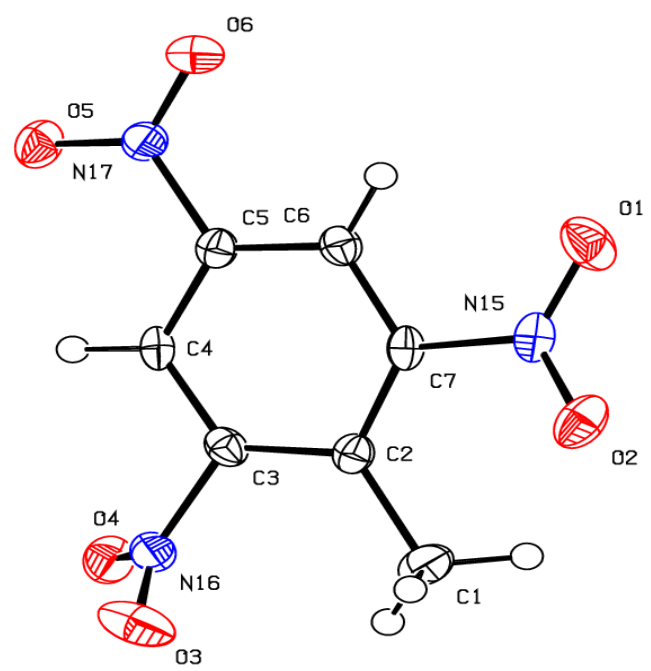

Fig. 4. ORTEP drawing of compound TNT-DAT 
The crystal data have been deposited in the Cambridge Crystallographic Data Centre; the CCDC number is 1582920 and the crystal data results indicated in Table 1 and the ORTEP drawing of TNT-DAT co-crystal are indicated in Figure 4.
The crystal structure of the TNT-DAT cocrystal was determined by single-crystal X-ray diffraction data and is indicated in Table 1 . The crystal data have been deposited in the Cambridge Crystallographic Data Centre; the CCDC number is 1582920 .

Table 1

Single-crystal X-ray refinement factors for TNT-DAT

\begin{tabular}{|c|c|}
\hline Empirical formula & $\mathrm{C}_{14} \mathrm{H}_{15} \mathrm{~N}_{5} \mathrm{O}_{6}$ \\
\hline Formula weight & 349.31 \\
\hline Temperature/K & $173(2)$ \\
\hline Crystal system & monoclinic \\
\hline Space group & $\mathrm{P} 21 / \mathrm{n}$ \\
\hline $\mathrm{a} / \AA$ & $8.9568(5)$ \\
\hline $\mathrm{b} / \AA$ & $15.0596(7)$ \\
\hline $\mathrm{c} / \AA$ & $11.4134(6)$ \\
\hline$\alpha /{ }^{\circ}$ & 90 \\
\hline$\beta /{ }^{\circ}$ & $97.993(5)$ \\
\hline$\gamma /{ }^{\circ}$ & 90 \\
\hline Volume $/ \AA^{3}$ & $1524.55(14)$ \\
\hline $\mathrm{Z}$ & 4 \\
\hline pcalc $\mathrm{g} / \mathrm{cm}^{3}$ & 1.522 \\
\hline$\mu / \mathrm{mm}^{-1}$ & 0.122 \\
\hline $\mathrm{F}(000)$ & 728 \\
\hline Crystal size $/ \mathrm{mm}^{3}$ & $0.789 \times 0.242 \times 0.12$ \\
\hline Radiation & $\operatorname{MoK} \alpha(\lambda=0.71073)$ \\
\hline $2 \Theta$ range for data collection $/{ }^{\circ}$ & 6.066 to 59.374 \\
\hline Index ranges & $-11 \leq \mathrm{h} \leq 11,-20 \leq \mathrm{k} \leq 19,-15 \leq 1 \leq 15$ \\
\hline Reflections collected & 26705 \\
\hline Independent reflections & $3974\left[\mathrm{R}_{\mathrm{int}}=0.0514, \mathrm{R}_{\text {sigma }}=0.0382\right]$ \\
\hline Data/restraints/parameters & $3974 / 0 / 228$ \\
\hline Goodness-of-fit on F2 & 1.102 \\
\hline Final $R$ indexes $[\mathrm{I}>=2 \sigma(\mathrm{I})]$ & $\mathrm{R}_{1}=0.0879, \mathrm{wR}_{2}=0.1970$ \\
\hline Final $\mathrm{R}$ indexes [all data] & $\mathrm{R}_{1}=0.1083, \mathrm{wR}_{2}=0.2076$ \\
\hline Largest diff. peak/hole/e $\AA^{-3}$ & $1.00 /-0.54$ \\
\hline
\end{tabular}

TNT is an electron-poor $\pi$-system, whereas the co-former, 2,3-diaminotoluene, is an electronrich aromatic compound, so the main non-covalent interaction is between the electron-poor and electron-rich aromatic rings. When choosing electronrich aromatic ring substances, COSMOtherm [17] software was used to predict the likelihood of cocrystal formation by calculating the excess enthalpy of formation of the co-formers. The calculations were generated by the Turbomole package using the BP86 density functional with a TZVP34 basis set (BPTZVP-COSMO level of theory). The electrostatic potential surfaces of TNT and the coformer were calculated to understand the intermo- lecular interactions. The calculated electrostatic potential surfaces are depicted in Figure 5.

The structure of the TNT-DAT co-crystal is dominated by both $\pi-\pi$ (3.542 $\AA$ ) stacking interactions and hydrogen bonds. Monocoordinated $(2.301 \AA)$ and bicoordinated (2.466 and $2.490 \AA)$ amino-nitro interactions are clearly observed and are shown in Figure 6. TNT co-crystals with amines do not usually preferentially form bicoordinated (three-centered) amine-nitro interactions, as might be expected based on the interactions of nitroanilines reported in the literature [1819]. 


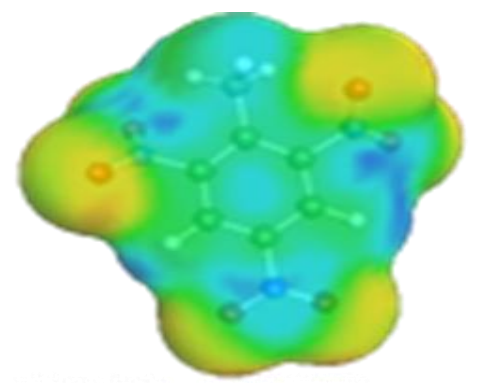

(a)

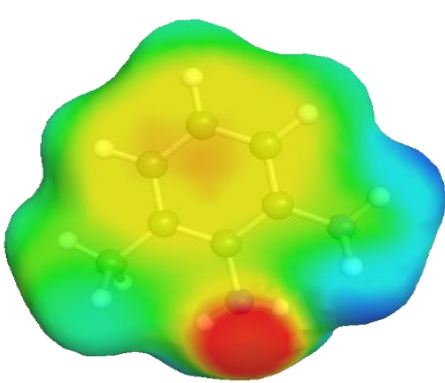

(b)

Fig. 5. Electrostatic potential surfaces of (a) TNT and (b) 2,3-diaminotoluene

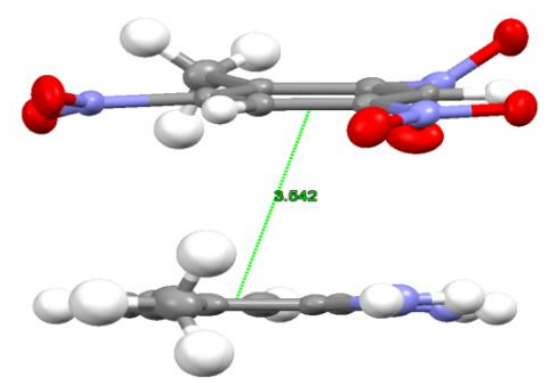

(a)

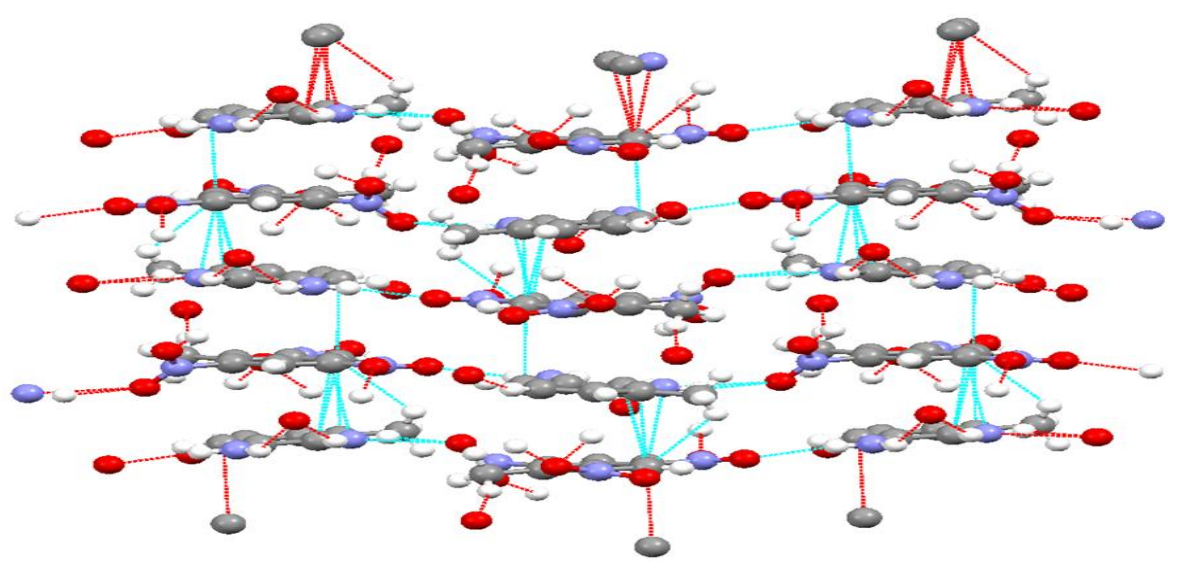

(b)

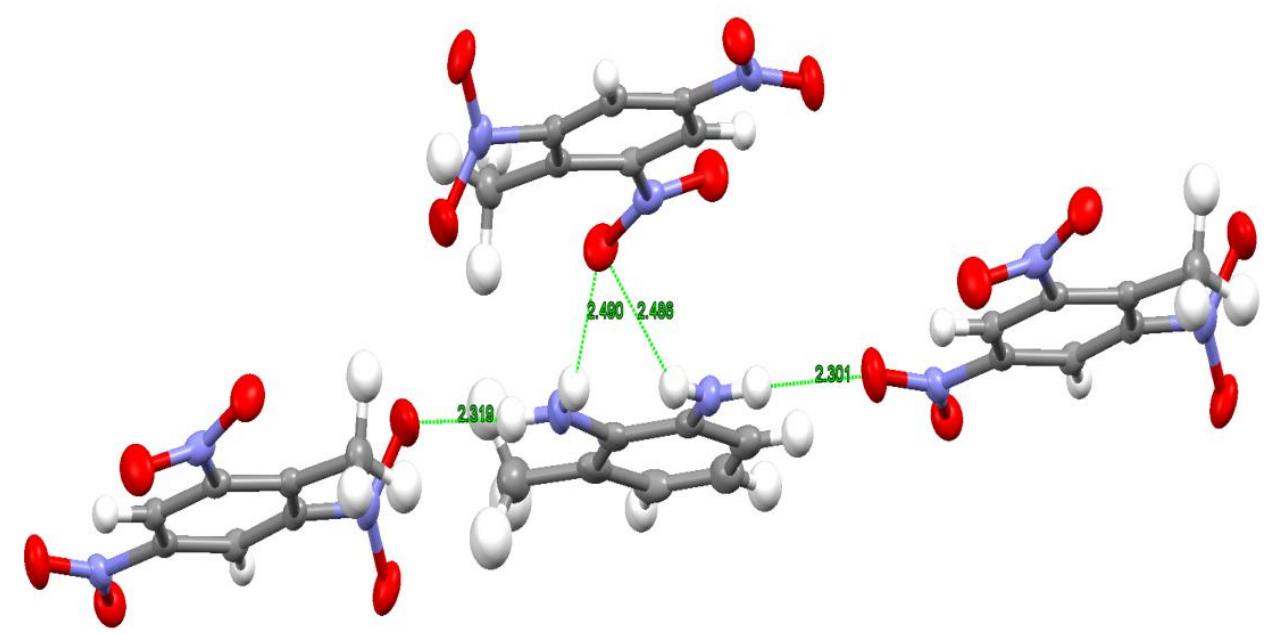

(c)

Fig. 6. Intermolecular interaction between TNT and 2,3-diaminotoluene:

(a) $\pi-\pi$ stacking, (b) non-covalent interaction (aqua color lines) and (c) amine-nitro 


\subsection{ATR-infrared spectroscopy}

The formation of co-crystals with TNT both changes the $\pi$-stacking motif of the co-crystal formers and notably reorients the nitro groups of the TNT molecule. Especially, there is a significant alteration in the angle of the nitro group in the 4position of TNT in the TNT-DAT co-crystal. In monoclinic TNT, these nitro groups of nonequivalent molecules make angles of 33.7 and $23.7^{\circ}$ to the benzene ring and the TNT-DAT cocrystal torsion angle is $3.980^{\circ}$.

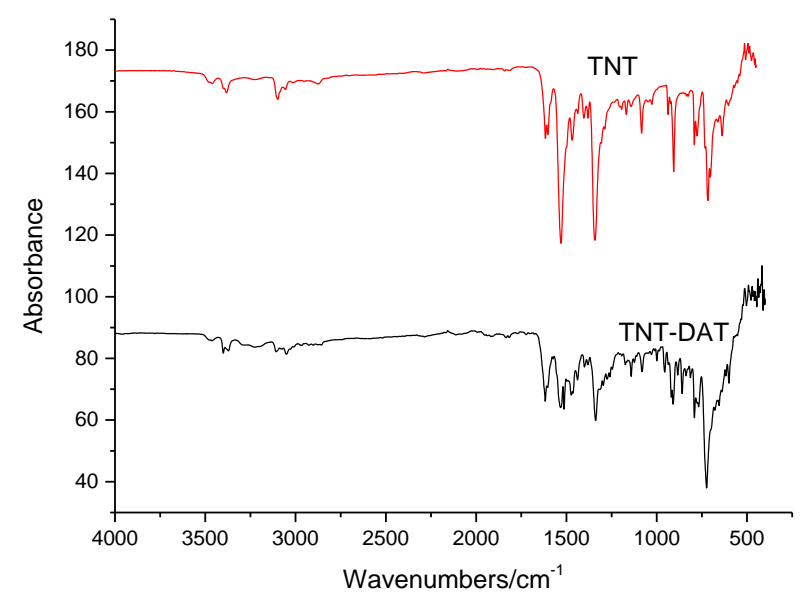

Fig. 7. Comparison of ATR-Infrared spectrum patterns for TNT and TNT-DAT

The alteration in orientation of the nitro groups affects the structure properties of TNT within the co-crystal. In fact, the alteration in the orientation of the nitro groups is important enough that it results in shifts in the vibrational spectra of this material. The IR spectra of TNT and TNTDAT are indicated in Figure 7. Monoclinic TNT has an asymmetric nitro stretch $\left(v_{\text {as }}\right)$ at $1532 \mathrm{~cm}^{-1}$ and a symmetric nitro stretch $\left(v_{\mathrm{s}}\right)$ at $1347 \mathrm{~cm}^{-1}$. In the TNT-DAT co-crystal, the asymmetric nitro stretch $\left(v_{\text {as }}\right)$ is at $1529 \mathrm{~cm}^{-1}$ and the symmetric nitro stretch $\left(v_{\mathrm{s}}\right)$ at $1336 \mathrm{~cm}^{-1}$. At the same time, some peak shifts can be attributed both to the hydrogen bonding and to the $\pi$ - $\pi$ stacking, which alter the symmetry characteristics in the co-crystal structure.

\subsection{Hirshfeld surface analysis}

Examination of intermolecular interactions using Hirshfeld surface-based tools indicates a prominent advance in enabling supramolecular chemists and crystal engineers to gain insight into crystal packing behavior [20]. Hirshfeld surfaces provide a three-dimensional picture of close contacts in a crystal, and these contacts can be summarized in a fingerprint plot. For this purpose, Crystal Explorer 17 was used; the Hirshfeld surfaces of TNT-DAT are shown in Figure 8. The H...O interactions comprise $25.7 \%$ of the total Hirshfeld surface and appear as narrow spikes in the fingerprint plot. The $\pi-\pi$ (C...C) interactions also have a relatively high contribution $(12.6 \%)$ to the total Hirshfeld surface of the co-crystal and appear as the large spike in the middle of the 2-D fingerprint plot. These highlight the close contacts between the molecules of TNT and 2,3-diaminotoluene.

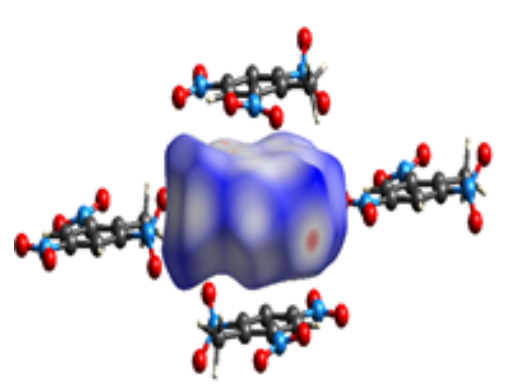

(a)



(b)

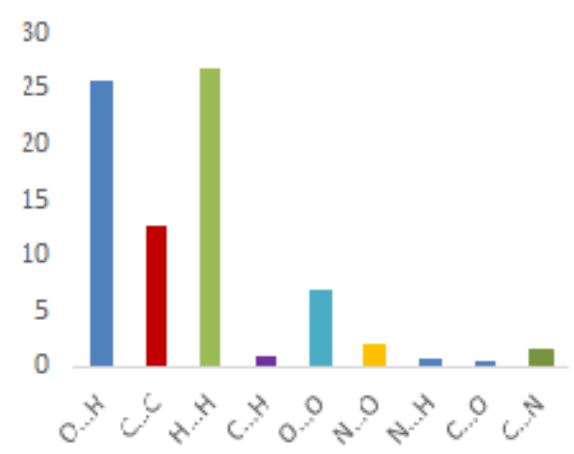

(c)

Fig. 8. (a) Hirshfeld surface analysis, (b) the two-dimensional fingerprint and (c) the contact contribution ratio between TNT and TNT-DAT 


\subsection{Oxygen balance}

Oxygen balance is a crucial factor to consider for energetic materials. It affects both the explosive power and the chemical products that might be produced on detonation or deflagration. In terms of the sensitivities of energetic materials, it has been suggested that energetic materials with an oxygen balance close to zero are more sensitive and desirable. Kamlet and Adolph showed that reasonable linear correlations between oxygen balance and $h_{50}$ (impact height) for some classes of energetic materials with the like decomposition mechanisms. There are some simple relationships that relate impact sensitivities with predicted molecular properties, e.g. the oxygen balance of molecules [21]. Nitro-aromatic with alpha C-H linkage for a $\mathrm{C}-\mathrm{H}-\mathrm{N}-\mathrm{O}$ type energetic materials, $\mathrm{h}_{50}$, oxygen balance $\left(\mathrm{OB}_{100}\right)$ and impact energy have been calculated by using equation $3.1,3.2$ and 3.3 respectively.

$$
\begin{gathered}
\log \mathrm{h}_{50 \%}=1.33-0.26 \mathrm{OB}_{100} \\
\mathrm{OB}_{100}=100(2 \mathrm{no}-\mathrm{nH}-2 \mathrm{nC}-2 \mathrm{nCOO}) \text { mol. mass }
\end{gathered}
$$

Impact energy $=$ Mass. Acceleration $\cdot$ Impact height $\left(\mathrm{h}_{50}\right)$

The $\mathrm{OB}_{100}$ of TNT-DAT is -0.3 , while that of TNT is -0.38 . TNT-DAT and TNT impact energy calculated by using equation 3.3 and found $36.40 \mathrm{~J}$ and $49.4 \mathrm{~J}$, respectively.

\subsection{Sensitivity}

The structure-safety relationship of energetic materials is of high interest, due to safety and energy being most important properties of energetic materials. Usually, safety is experimentally estimated by sensitivity; a higher sensitivity represents a lower safety. The structures should be responsible for the sensitivity, as properties and performances are always determined by structures. Co-crystallization of explosive materials with nonenergetic materials can often enhance the performance of explosives by decreasing the sensitivity to impact and improving chemical and thermal stability. Previous research has indicated that various factors can affect properties such as crystal packing, density, oxygen balance within the molecular structure, intermolecular hydrogen bonding, long and short-range interactions, voids, defects, thermal stability, decomposition and molecular motion within a crystal lattice [22].

Four types of stacking are used to clarify the crystal packing and to rationalize the effect of stacking on impact sensitivity. All $\pi$-stacking can be classified: face-to-face stacking, wavelike stacking, crossing stacking and mixed stacking [23]. Apparently, a perfect face-to-face $\pi$-stacking is highly desirable for impact-sensitive energetic materials with a high molecular stability. In fact, perfect face-to-face $\pi$-stacked energetic materials are seldom seen. 1,3,5-triamino-2,4,6-trinitrobenzene (TATB) is the so-called wood explosive with nearly the lowest impact sensitivity in all explosives and excellent thermal stability. This high molecular stability contributes to the very low impact sensitivity of TATB [24]. It is strong extremely long $\mathrm{C}-\mathrm{C}$ bonds in the benzene ring, very short $\mathrm{C}-$ $\mathrm{N}$ (amino) bonds and six furcated hydrogen bonds [25]. Furthermore, there is an evidence of strong inter- and intra- molecular hydrogen bonds in TATB. The hydrogen bonding helps the face-toface $\pi$-stacking and makes some energetic materials impact-insensitive. In the structure of the new TNT-DAT co-crystal, face-to-face stacking occurs along the molecular plane and represents a facile sliding mechanism, as indicated in Figure 9, and suggests that this TNT-DAT co-crystal would exhibit low impact sensitivity.

Supposedly, there should be a link between the packing structure and impact sensitivity. Significantly, this link could be the sensitivity mechanism. Initially, an impact acts on an energetic material, leading to compression and shear sliding. Earlier works indicated that the shear sliding behavior leads the impact sensitivity mechanism [2629]. The external mechanical energy is stored as increased stress; fundamentally, increased intraand intermolecular potentials. Then, yields and defects are formed, and the temperature increases through strain increase. Some molecules around the defects are primary triggered and decomposed, with heat accumulation leading to more molecular decomposition. Hot spots expand resulting in combustion and detonation. It is thought that hot-spot formation and growth is significant in the ignition of energetic materials.

In the TNT-DAT co-crystal, hydrogen bonding-aided face-to-face $\pi$-stacking makes it less sensitive and more stable than TNT. TNT-DAT and TNT impact energy found $36.40 \mathrm{~J}$ and $49.4 \mathrm{~J}$, respectively. It showed that TNT-DAT is more impact-insensitive than TNT; while, interestingly, TNT-DAT could be analyzed thermally at the comparatively low decomposition temperature of $244{ }^{\circ} \mathrm{C}$, below that of TNT, $298{ }^{\circ} \mathrm{C}$. In this instance, the comparatively low thermal stability of TNT-DAT is mostly caused by its comparatively low molecular stability. 


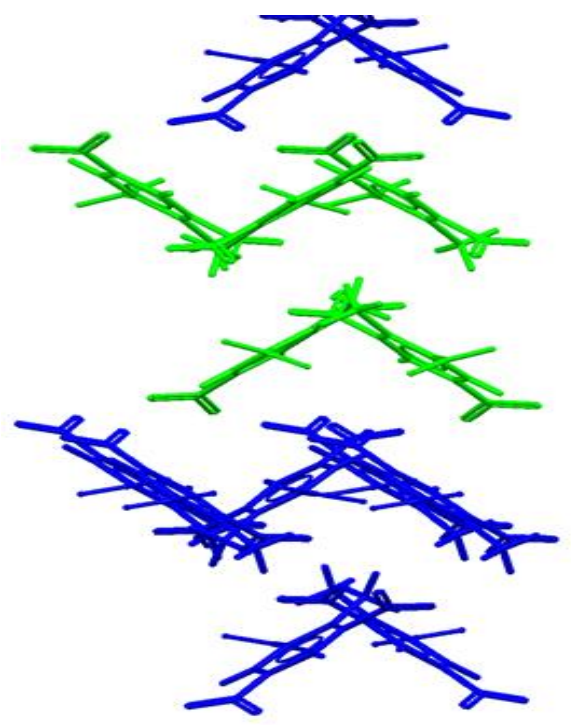

(a)

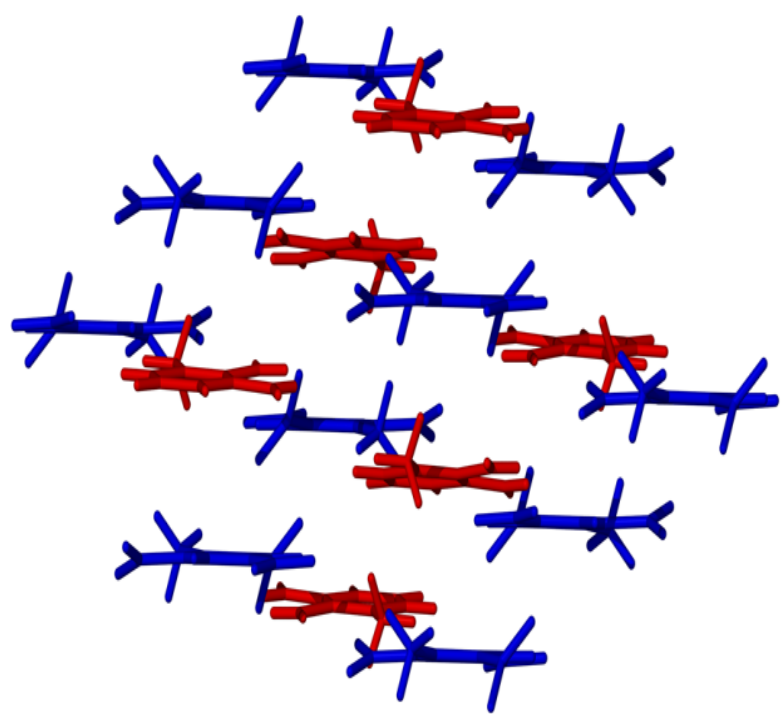

(b)

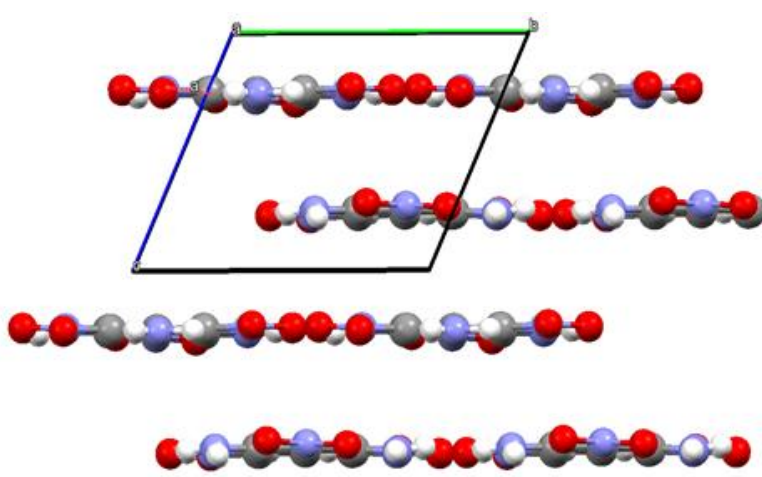

(c)

Fig. 9. (a) A comparison of the herringbone packing of monoclinic TNT (CSD code ZZZMUC08) [30], (b) the face-to-face $\pi$-stacking of the TNT-DAT co-crystal and (c) TATB.

\section{CONCLUSIONS}

A new energetic co-crystal explosive composed of TNT and 2,3-diaminotoluene in a 1:1 molar ratio was successfully synthesized and characterized. The TNT-DAT co-crystal exhibits both $\pi$ $\pi$ stacking interactions and hydrogen bonding interactions (amino-nitro). The crystal packing of TNT-DAT is $\pi-\pi$ stacking, with the help of intermolecular hydrogen bonding supporting layers. Face-to-face sliding planes in TNT-DAT, combined with strong intermolecular bonds, could potentially lead to reduced impact sensitivity of this co-crystal. Furthermore, the change in oxygen balance also suggests that the co-crystal is less sensitive. Impact sensitivity measurement are planned in order to confirm these predictions. Properties crucial to energetic materials, including the density, decomposition temperature and sensitivity were successfully altered through co-crystallization.
Acknowledgments. Nilgün Sen thanks the TUBITAKBIDEB 2219-International Postdoctoral Research Fellowship Program for financial support for the project and Professor Colin Pulham continued supervision and support throughout this project. Dr. Gary Nichol for collecting single-crystal data sets at the X-ray service department at the University of Edinburgh, Finally I would like to thank Dr. Adam A.L. Michalchuk and Karl S. Hope for valuable feedback.

\section{REFERENCES}

[1] J. Akhavan, The Chemistry of Explosives., 3rd ed., RSC Press, Cambridge, UK, 2011, pp.1-2, ISBN 978-184973-330-4.

[2] A. K. Sikder, N. Sikder, A review of advanced high performance, insensitive and thermally stable energetic materials emerging for military and space applications. J. Hazard. Mater. 112 (1-2), 1-15 (2004). DOI:10.1016/j. jhazmat.2004.04.003

[3] F. P. A. Fabbiani, C. R. Pulham, High-pressure studies of pharmaceutical compounds and energetic materials, Chem. Soc. Rev. 35 (10), 932-942 (2006). DOI:10.1039/B517780B 
[4] J. Evers, T. M. Klapötke, P. Mayer, G. Oehlinger, J. Welch, $\alpha$ - and $\beta$-FOX-7, polymorphs of a high energy density material, studied by X-ray single crystal and powder investigations in the temperature range from 200 to 423 K., Inorg. Chem., 45 (13), 4996-5007 (2006). DOI: $10.1021 / \mathrm{ic} 052150 \mathrm{~m}$.

[5] W. C. McCrone, Cyclotetramethylene tetranitramine (HMX), Anal. Chem., 22 (9), 1225-1226 (1950).

[6] D. J. Berry, C. C. Seaton, W. Clegg, Applying hot-stage microscopy to co-crystal screening: A study of nicotinamide with seven active pharmaceutical ingredients, Cryst Growth Des., 8(5), 1697-1712 (2008). DOI:10.1021/cg800035w

[7] N. Chieng, M. Hubert, D. Saville, T. Rades, J. Aaltonen, Formation kinetics and stability of carbamazepinenicotinamide cocrystals prepared by mechanical activation, Cryst Growth Des., 9(5), 2377-2386 (2009). DOI:10.1021/cg801253f

[8] D. R. Weyna, T. Shattock, P. Vishweshwar, M. J. Zaworotko, Synthesis and structural characterization of cocrystals and pharmaceutical cocrystals: Mechanochemistry vs slow evaporation from solution, Cryst Growth Des., 9(2):1106-1123 (2009). DOI:10.1021/cg800936d

[9] J. C. Barnes, W. Golnazarians, The 1:1 complex of pyrene with 2,4,6-trinitrotoluene, Acta Cryst., C43, 549552 (1987).

[10] Kb. Landenberger, A. J. Matzger, Cocrystal engineering of a prototype energetic material supramolecular chemistry of 2,4,6-trinitrotoluene. Crystal Growth \& Design., 10(12), 5341-5347 (2010). DOI:10.1021/cg101300n

[11] O. Bolton, A. J. Matzger, Improved stability and smartmaterial functionality realized in an energetic cocrystal. Angew. Chem. Int. Ed., 50, 8960-8963 (2011). doi.org/10.1002/anie.201104164.

[12] Z. Yang, H. Li, H. Huang, X. Zhou, J. Li, F. Nie, Preparation and performance of a HNIW/TNT cocrystal explosive, Propellants, Explos Pyrotech., 38(4), 495-501 (2013). DOI:10.1002/prep.201200093

[13] J. B. Ledgard, The Preparatory Manual of Explosives. 3rd ed., Washington, USA, 2007, pp. 180; ISBN 13: 978-0615142906

[14] O. V. Dolomanov, L. J. Bourhis, R. J. Gildea, J. A. K. Howard, H. Puschmann, OLEX2: A complete structure solution, refinement and analysis program, J. Appl Crystallogr., 42(2), 339-341 (2009). DOI:10.1107/S0021889808042726

[15] G. M. Sheldrick, Crystal structure refinement with SHELXL. Acta Crystallogr. Sect. C Struct. Chem., A71, 3-8 (2015). DOI:10.1107/S2053229614024218

[16] G. M. Sheldrick, Crystal structure refinement with SHELXL. Acta. Crystallogr. Sect. C Struct. Chem., C71, 3-8 (2015).

[17] C. Loschen, A. Klamt, COSMO quick: A novel interface for fast $\sigma$-profile composition and its application to
COSMO-RS solvent screening using multiple reference solvents, Ind. Eng. Chem. Res., 51(43), 14303-14308 (2012). DOI:10.1021/ie3023675.

[18] M. E. Etter, Hydrogen Bonds as Design Elements in Organic Chemistry, Journal Phys. Chem. 95(8), 46014610 (1991). DOI:10.1021/j100165a007.

[19] T. W. Panunto, Z. Urbinczyk-Lipkowska, R. Johnson, M. C. Etter, Hydrogen-bond formation in nitroanilines: The first step in designing acentric materials, J. Am. Chem. Soc., 109(25), 7786-7797 (1987). DOI:10.1021/ja00259a030.

[20] H. F. Clausen, M. S. Chevallier, M. A. Spackman, B. B. Iversen, Three new co-crystals of hydroquinone: crystal structures and hirshfeld surface analysis of intermolecular interactions, New J. Chem. 34(2), 193-199 (2010). DOI:10.1039/B9NJ00463G.

[21] M. J. Kamlet, H. G. Adolph, The relationship of impact sensitivity with structure of organic high explosives, II. Polynitroaromatic explosives. Propellants, Explos. Pyrotech., 4(2), 30-34 (1979). DOI:10.1002/prep.19790040204.

[22] Y. Ma, A. Zhang, X. Xue, D. Jiang, Y. Zhu, C. Zhang, Crystal packing of impact-sensitive high-energy explosives, Cryst Growth Des., 14(11), 6101-6114 (2014). DOI:10.1021/cg501267f

[23] Y. Ma, A. Zhang, C. Zhang, D. Jiang, Y. Zhu, C. Zhang, Crystal packing of low-sensitivity and high-energy explosives, Cryst Growth Des., 14(11), 4703-4713 (2014). DOI:10.1021/cg501048v

[24] H. H. Cady, A. C. Larson, The crystal structure of 1,3,5triamino-2,4,6-trinitrobenzene, Acta Crystallographica, 18, 485-496 (1965).

[25] J. R. Kolb, H. F. Rizzo, Growth of 1,3,5-triamino-2,4,6trinitrobenzene (TATB). I. Anisotropic thermal expansion. Propellants and Explosives, 4, 10-16 (1979).

[26] C. Zhang, X. Wang, H. Huang, $\pi$-Stacked interactions in explosive crystals: Buffers against external mechanical stimuli, J. Am. Chem. Soc. 130(26), 8359-8365 (2008). DOI:10.1021/ja800712e

[27] J. J Dick, Effect of crystal orientation on shock initiation sensitivity of pentaerythritol tetranitrate explosive, Appl. Phys. Lett., 44(9), 859-861 (1984). DOI:10.1063/1.94951

[28] M. M. Kuklja, S. N. Rashkeev, Interplay of decomposition mechanisms at shear-strain interface, J. Phys. Chem. C. 113(1), 17-20 (2009). DOI:10.1021/jp808367r

[29] C. Zhang, X. Xue, Y. Cao, Intermolecular friction symbol derived from crystal information, Cryst. Eng. Comm. 5(34), 6837 (2013). DOI:10.1039/c3ce40817e

[30] R. M. Vrcelj, J. N. Sherwood, A. R. Kennedy, H. G. Gallagher, T. Gelbrich, Polymorphism in 2-4-6trinitrotoluene, Cryst. Growth. Des. 3(6), 1027-1032 (2003). DOI:10.1021/cg0340704. 
